\title{
Expresívnost' literárnej tvorby Leonida Andrejeva v kontexte sústavy výrazových kategórií Františka Mika
}

\section{The Expressiveness of Leonid Andreyev's Literary Works in the Context of František Miko's System of Expression Categories}

Natália Dúbravská

(Banská Bystrica, Slovenská republika)

\section{Абстракт:}

Štúdia identifikuje paralely medzi poetikou Leonida Andrejeva, jedného z popredných predstavitel’ov ruskej literárnej moderny, a literárnym expresionizmom. Pri skúmaní danej problematiky sa autor štúdie opiera o ideovo-estetický program spisovatelovej tvorby na pozadí literárneho kánonu na prelome 19. a 20. storočia, ktorý slúži ako premisa pre d’alšiu interpretáciu špecifík Andrejevovej poetiky. Východiskom analýzy Andrejevovej expresívnosti na ploche štúdie je sústava výrazových kategórií a kategória expresívnosti definovaná podla Františka Mika, na základe ktorej autor štúdie definuje expresívny prvok v Andrejevovej tvorbe ako produkt sémantickej disproporcie medzi objektom a subjektom s presahom na tematickej a jazykovej rovine prozaických a dramatických diel spisovatela.

\section{Kl'účové slová:}

Leonid Andrejev; expresívnost'; expresionizmus; František Miko; sústava výrazových kategórií

\section{Abstract:}

The study identifies the parallels between the poetics of Leonid Andreyev, one of the leading figures of Russian literary modernism, and literary expressionism. The author of the study uses the ideological and aesthetic program of the writer's work in the 
context of literary canon at the turn of the 19th and 2oth centuries as a basis for her research. The author defines the expressive element in Andreyev's work as a product of semantic disproportion between object and subject (based on František Miko's system of expression categories and his category of expressiveness) that manifests on both thematic and linguistic level of writer's prosaic and dramatic works.

\section{Key words:}

Leonid Andreyev; expressiveness; expressionism; František Miko; system of expression categories

\section{Úvod}

Princípy literárneho expresionizmu ako nového umeleckého smeru, ktorý sa sformoval v opozícii ku klasickému realizmu v prvých dekádach 20. storočia, našli odozvu aj v prostredí predrevolučného Ruska. Jedným z prvých predstavitelov literárneho expresionizmu v Rusku (a zároveň aj vo svete) sa stal prozaik a dramatik Leonid Andrejev. Andrejev na ploche svojich diel využíval expresionistické prostriedky ako médium na vyjadrenie ambivalentnosti a antagonizmu spoločenskej atmosféry na prelome dvoch storočí, ktoré boli dôsledkom dobových geopolitických a gnozeologických otrasov. Expresívna poetika mu poskytovala dostatočnú variabilitu pri uchopovaní a interpretovaní vlastných duševných poryvov a konfliktných postojov vo vztahu $\mathrm{k}$ zeitgeistu doby.

V autorových dielach sa do popredia dostáva konflikt na osi subjekt - objekt, ktorý má presah na tematickej, ako aj na jazykovej rovine diela a predstavuje ústredný motív expresionisticky koncipovanej literatúry. Účelovú amplifikáciu subjektu na úkor objektu v diele spisovatela, príznačnú pre literárny expresionizmus, možno traktovat' cez optiku sústavy výrazových kategórií Františka Mika, ktorú slovenský jazykovedec po prvýkrát predstavil vo svojej monografii Estetika výrazu. Mikova výrazová sústava v predloženej štúdii poslúži ako platforma pre detailnejšiu analýzu špecifík Andrejevovej poetiky v intenciách kategórie expresívnosti.

\section{Ideové determinanty v pozadí literárnej tvorby Leonida Andrejeva}

\subsection{Revolta ako základná premisa literárneho expresionizmu}

Poetika ruského prozaika a dramatika Leonida Andrejeva svojou experimentálnou tvárnostou vyhranenou voči konvenciám súdobého literárneho diskurzu vniesla na prelome 19. a 20. storočia do literárnej sféry prvok diskontinuity. Na ploche 
spisovatelovej tvorby došlo oproti predchádzajúcemu systému tradovaných literárno-estetických kategórií k výraznému posunu na tematickej, ako aj na jazykovej rovine diela. Andrejev svojím idiolektom v duchu nietzscheánskej požiadavky prehodnotenia všetkých hodnôt, charakteristickej pre ideový program súdobých formujúcich sa myšlienkových prúdov, prekonal doznievajúci kánon realistickej tradície a vytvoril tak priestor pre koncipovanie novej, expresívnej tvorivej metódy, založenej na relativizácii a negácii existujúcich estetických hodnôt.

Ideová osnova Andrejevovej novosformovanej poetiky, predznamenávajúcej nástup literárneho expresionizmu, vychádzala z potreby účelovej deestetizácie a deformácie charakteru prozaického a dramatického textu, ako výrazu ideovej subverzie voči postulátu „ideologických a institucionálních “1 intersubjektívnych konvencií, ktoré v literatúre na prelome storočí zosobňoval klasický realizmus. Spisovatel' svoj idiolekt budoval na konfrontácii umeleckých kategórií, ktoré boli v úvode 20. storočia „,estetizovány“ prostrednictvím konvenčních"2 "interpretačních a orientačních soustav"3.

V jadre novej tvorivej metódy spisovatela sa po vzore manifestu expresionistického hnutia koncentroval prvok revolty, ktorý mal za ciel’ zabezpečit’, že „základní premisu výstavby expresionistické skutečnosti predstavuje neustálé zpochybňování všech ideologických a epistemických základi̊, všech tradovaných modelü reality $a$ všech etablovaných struktur vnímání a proživání“4 . Expresionistický ikonoklazmus odzrkadloval stav sociálnej anómie modernej doby vychádzajúcej z epistemologickej skepsy ako sprievodného javu transformujúcej sa spoločnosti. Koniec 19. storočia bol v optike súčasníkov interpretovaný ako kolaps predchádzajúceho sveta a jeho gnozeologických pilierov, ktorého vyústením bol pretrvávajúci stav spoločenskej paralýzy a krízy hodnôt. Podmienkou nevyhnutného spoločenského prerodu malo byt' zanechanie „atavizmu“ epistemologického obrazu dovtedajšieho sveta a jeho prekonanie novou gnozeologickou podstatou.

Táto idea epistemologického zlomu, ktorej jedným z prvých priekopníkov bol Friedrich Nietzsche, si našla svojich prívržencov v umení a udomácnila sa aj na poli literatúry. Nietzscheho povestná téza „boh je mŕtvy “5 sa stala symbolom konca jednej epochy a jej hodnotového rámca. Túto myšlienku si po jeho vzore osvojili aj predstavitelia rodiacich sa umeleckých a literárnych smerov. Podla expresionistov sa jeden svet „zhroutil [...]. Náboženství, věda i morálka jsou úkazy vyvolané existenci úzkostnými stavy primitivních národů. Hroutí se tisíc let kultury. Žádné sloupy a opory,

1 MURPHY, R.: Teoretizace avantgardy: modernismus, expresionismus a problém postmoderny. Brno: Host, 2010, s. 54 .

2 Tamže, s. 60.

3 Tamže, s. 56.

4 Tamže, s. 55.

5 NIETZSCHE, F.: Tak vravel Zarathustra. Kniha pre všetkých a pre nikoho. Bratislava: Iris, 2002, s. 8. 
žádné základy nebyly ušetřeny demolice“" . Zánik jednej prekonanej paradigmy však automaticky predpokladal vznik novej - takej, ktorá by väčšmi reflektovala požiadavky človeka ako jednotlivca.

\subsection{Iluzórnost' diskurzívnej reality a „žalár“ jazyka}

V optike expresionistov sa záver jednej etapy v genéze ludských dejín niesol v znamení kolapsu konvenčného spoločenského diskurzu. Dovtedajší diskurz mal v ich ponímaní charakter iluzórneho myšlienkového systému, ktorého implikácie v empirickom svete existovali len $\mathrm{v}$ hypotetickej rovine a nemali naň priamy dosah. Túto skutočnost’ zdôvodňovali jeho neukotvenostou v „prírodnom zákone“. Išlo podla nich „o člověkem postulované významové struktury, uvalené na svět jevũ s cílem dát mu formu a získat nad ním moc "7 . Takáto abstrakcia však nemohla pretendovat’ na preskriptívnu normu.

$S$ príchodom 20. storočia sa prekonaný spoločenský diskurz, u ktorého absentoval empirický základ, stal objektom skepticizmu. Nová doba znamenala „zásadní prưzkum skutečnostního diskurzu a odhalování fikčnosti všech oněch „podstat", v nichž je ukotven systém smyslu"8. Fikcia dovtedajšieho diskurzu podla expresionistov spočívala práve v spôsobe, akým uchopoval zmysel. Zmysel bol podla nich produktom sémantickej aktivity, ktorá za pomoci jazyka a fikcie dodala empirickej skúsenosti formu. Cielom tejto aktivity bolo „vytvořit zpodobovací kódy a ideologické formace, které prezentují

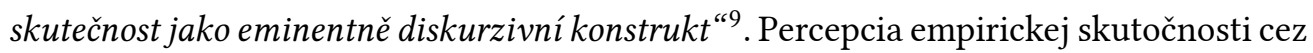
prizmu diskurzu evokovala pocit izolácie od iných skúsenostných modalít a odcudzenia od skutočného bytia. Nietzsche nazval tento druh izolovanosti v ideologickom mikrokozme fikcií „žalárom“ jazyka, t. j. uzatvorenou mašinériou bez empirického presahu, v ktorej subjekt stratil kontakt s realitou a mylne sa riadil postulátmi, ktoré $\mathrm{v}$ skutočnosti predstavovali konštrukt.

\subsection{Deestetizácia a princíp disonancie ako základné predpoklady expresívnej poetiky}

V úvode 20. storočia vzniká v optike expresionistov potreba nahradit’ doznievajúci fiktívny diskurz novým, antinomickým diskurzom. Takýto expresionistický „kontradiskurz" mal byt podla nich zbavený „sublimity, estetizace i organické formy“10 - mal

6 MURPHY, R.: Teoretizace avantgardy: modernismus, expresionismus a problém postmoderny. Brno: Host, 2010, s. 55 .

7 Tamže, s. 56.

8 Tamže, s. 57.

9 Tamže, s. 57.

10 Tamže, s. 59. 
teda negovat takmer všetky princípy, ktoré tvorili gro predchádzajúceho estetického diskurzu. Jeho podstata tkvela v negácii organickosti. Mal teda rekodifikovat’ a substituovat’ to, čo bolo doposial percipované ako „prirodzené“. Namiesto organickosti presadzoval kontradiskurz primát frapantnej artificiality. Táto deestetizačná tendencia ostro kontrastovala $\mathrm{s}$ inklináciou štandardného umenia $\mathrm{k}$ reprodukcii a oslave prirodzeného sveta. Kontradiskurz sa v tomto smere nesnažil po vzore masového umenia umelost' potláčat', ale naopak, v rozpore s tradovaným kánonom, ju staval na piedestál.

Dominantné konvencie prekonaného estetického diskurzu sa z pohladu expresionistov snažili navodit’ falošnú ilúziu harmónie a systematickosti. Práve v takomto idealizovaní skutočnosti však expresionisti videli prvok neprirodzenosti a faloše. Vo svojom manifeste sa preto snažili prevrátit tradované hodnotové hierarchie, „které kladou vznešené výše než okrajové a prirrozené výše než uměle“ “11, a dosiahnut" tak „tvưrčí ,přepis'světa jakožto konstruktu lidského vědomi i"12 a oslobodenie sveta od „,hodnot a postojů odkázaných tradici“"13.

Snaha o zvrátenie estetizačných tendencií dominantného diskurzu a presadzovanie artificiality na úkor organickosti je prominentná aj na ploche literárnej tvorby Leonida Andrejeva. Tvorbu ruského spisovatela možno v tomto smere interpretovat' ako „reakciu na samoúčelnost' estetického tvaru“"14, ktorú v podobe umeleckého programu presadzoval v rovine diskurzu dominantný formalizmus. Autor sa na ploche diel ostro vyhranil voči pravidlám „ustanovenej jazykovej hry“15 formalizmu a primátu estetickej formy, ktorý potláčal funkciu umeleckého textu ako média slúžiaceho na vyjadrenie subjektívneho zážitku, a limitoval úlohu spisovatela vo vzt’ahu k literárnemu dielu na obyčajného mediátora estetickej hry. Andrejev vo svojej optike literárny text neredukoval na bezprostredný „objekt estetického vnímania“16 zbavený subjektivity, ktorý „sa rozvíja zvonku, od formy a nie zvnútra, od zážitku“17. Próza a dráma mala v jeho ponímaní naopak slúžit predovšetkým ako platforma pre híbkovú introspekciu spisovatela, v prípade potreby realizovanú aj na úkor formy. Namiesto „prázdneho

11 Tamže, s. 65.

12 Tamže.

13 Tamže.

14 MIKO, F.: Estetika výrazu: teória výrazu a štýl. Bratislava: Slovenské pedagogické nakladatelstvo: Pedagogická fakulta v Nitre, Kabinet literárnej komunikácie, 1969. s. 108.

15 HABERMAS, J.: Teória jazyka a východiská sociálnych vied: (úvodné štúdie a dodatky $k$ teórii komunikatívneho konania). Bratislava: Kalligram, 2011. s. 327.

16 MIKO, F.: Estetika výrazu: teória výrazu a štýl. Bratislava: Slovenské pedagogické nakladatelstvo: Pedagogická fakulta v Nitre, Kabinet literárnej komunikácie, 1969. s. 67.

17 Tamže, s. 108. 
formalistického hračkárstva "18 upriameného najmä na estetickú tvárnost’ znaku preto prozaik vo svojej tvorbe $\mathrm{v}$ rozpore $\mathrm{s}$ dobovým konvencionalizmom presadzoval maximálnu komunikatívnost'.

Okrem povyšovania funkcie literárneho diela na úkor formy a uprednostňovania artificiality na úkor organickosti dosahovali expresionisti antiestetické vyznenie textu aj prostredníctvom navodzovania dojmu chaosu vyplývajúceho z deformovaného reflektovania skutočnosti. Táto tendencia vychádzala z reverznej stratégie usilujúcej sa o prevrátenie konvenčných estetických hodnôt. Jej cielom bolo podkopanie tradičných topoi vlastných predovšetkým klasickému realizmu, pre ktorý bola charakteristická snaha o nadmernú objektivizáciu, systemizáciu a racionalizáciu skutočnosti. Expresionizmus sa naopak pokúšal o budovanie antinomického obrazu makrokozmu vyznačujúceho sa asystematickým, asymetrickým, disharmonickým a subjektívnym percipovaním skutočnosti, ktoré popieralo „iluzórnu“ predstavu klasického realizmu o ucelenom obraze sveta a semiotickej hegemónii. Realita bola podla expresionistov iracionálna a fragmentárna - nebolo možné ju rozumovo poňat', ani systematicky uchopit'. Základným výrazovým prostriedkom expresionistov sa preto stala disonancia ako produkt chaotickej skutočnosti, ktorý našiel odozvu na tematickej i jazykovej rovine expresionistickej literatúry.

\section{Expresívnost ako produkt sémantickej disproporcie interpretovanej cez prizmu sústavy výrazových kategórií Františka Mika}

\subsection{Antagonizmus objektu a subjektu}

Literárny expresionizmus bol podla slovenského literárneho vedca a jazykovedca Františka Mika, podobne ako iné smery literárnej moderny formujúce sa na prelome 19. a 20. storočia, výslednicou polarizácie „medzi estetickou hrou a vyjadrením životného zážitku "19, ktorá bola sprievodným javom rozporu medzi formalistickými a funkcionalistickými prístupmi k povahe prozaického diela. Antagonizmus týchto dvoch smerov sa v literatúre pretavil do dichotómie, v ktorej sa literárne dielo chápalo jednak „ako priamy objekt estetického vnímania, a jednak ako prostriedok na vyjadrenie zážitku“20, pričom oba tieto prístupy zintenzívnili „disonantný vztah medzi objektom a subjektom ako dvoma výrazovými pólmi literárneho textu“21.

\footnotetext{
18 Tamže, s. 67.

19 Tamže, s. 67.

20 Tamže.

21 DÚBRAVSKÁ, N.: Sémantická disproporcia a jej výrazové implikácie na ploche prekladov vybraných prozaických diel Leonida Andrejeva. Nová filologická revue, 2019, roč. 11, č. 1, jún 2019, s. 103.
} 
„Protikladné skíbenie subjektívneho a objektívneho prvku vo vyjadreni" “22, typické pre kategóriu expresívnosti, je v optike Mika základným stavebným elementom expresionisticky koncipovaného diela. Expresívnost', ktorú Miko bližšie definoval v rámci svojej sústavy výrazových kategóriî ${ }^{23}$, je podla neho špecifickým prejavom subjektívnosti výrazu. $V$ expresionistickom texte sa subjektívnost' uplatňuje vo väššej miere, čím „spôsobuje prevrátenie hierarchie objektu a subjektu vo vyjadrení v prospech subjektu“ ${ }^{\text {"24. }}$. Konflikt medzi subjektívnou a objektívnou zložkou na osi objekt - subjekt má podla Mika podobu „sémantickej disproporcie medzi objektívnou významovou zložkou a subjektívnym postojom podávatela “25. Pri sémantickej disproporcii v praxi na ploche literárneho diela dochádza $\mathrm{k}$ rozporu medzi subjektívnym aspektom postavy, ktorá slúži na reflektovanie vlastnej komunikačnej perspektívy rozprávača, a objektívnym prvkom reality. Z filozofického hladiska ide o neriešitelný tematický konflikt medzi subjektívnym chcením postavy a objektívnou nevyhnutnost’ou, ktorý spravidla končí rezignáciou postavy. Na rozdiel od prózy literárneho realizmu, v ktorej sa takýto konflikt odohráva len $\mathrm{v}$ rovine sujetovej výstavby, však v expresionizme konflikt na osi subjekt - objekt úmerne preniká do všetkých zložiek diela vrátane tej jazykovej.

Primát subjektívneho prvku v diele je podla Mika výrazom gesta autora, ktorým autor čitatelovi sugestívne podsúva vlastný, zaujatý pohlad na svet. Toto gesto „deformuje, resp. zvláštnym, neobvyklým spôsobom formuje objekt, vyjadrujúc tým subjektívne zaujatie, hodnotenie alebo výklad danej skutočnosti, spravidla v negatívnom

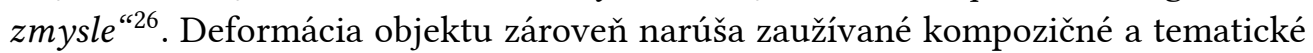
konvencie a prispieva $\mathrm{k}$ „deformácii jazyka a cezeň $i k$ deformácii toho, čo sa ním vyjadruje ${ }^{\text {227. }}$.

\section{2 Špecifiká expresívnosti v tvorbe Leonida Andrejeva}

Prvok disonancie, ktorý je produktom disproporciálneho vzt’ahu medzi subjektívnou a epickou zložkou textu v expresionizme, úmerne preniká prakticky celou Andrejevovou prozaickou a dramatickou tvorbou publikovanou po roku 1900. Zatial čo spisovatelove literárne prvotiny prevažne nadväzovali na tradíciu klasického realizmu

22 MIKO, F.: Estetika výrazu: teória výrazu a štýl. Bratislava: Slovenské pedagogické nakladatel’stvo: Pedagogická fakulta v Nitre, Kabinet literárnej komunikácie, 1969. s. 110.

23 Koncept sústavy výrazových kategórií F. Miko po prvýkrát predstavil v práci Estetika výrazu (1969). Vo svojej sústave vychádzal z Bühlerovho modelu jazykových funkcií.

24 MIKO, F.: Estetika výrazu: teória výrazu a štýl. Bratislava: Slovenské pedagogické nakladatelstvo: Pedagogická fakulta v Nitre, Kabinet literárnej komunikácie, 1969. s. 110.

25 Tamže, s. 63.

26 Tamže.

27 Tamže. 
(Баргамот и Гараська (1898), Петька на даче (1899), Ангелочек (1899) а i.), jeho práce z úvodu 20. storočia (Стена (1901), Бездна (1902), Красныцй смех (1904), Так было (1905) a i.) jednoznačne inklinovali k experimentálnemu naratívu umocnenému expresívnost’ou. Nosným nástrojom realizácie expresívnej disonancie v Andrejevovom diele je prvok antinómie, ktorý autor uplatňuje tak na tematickej, ako aj na jazykovej rovine textu.

V rovine témy má expresívna disonancia na ploche tvorby spisovatela podobu konfliktu typického pre expresívne koncipovanú literatúru. Jadrom tohto konfliktu je spravidla diskrepancia medzi objektívnym makrokozmom a subjektívnym mikrokozmom hlavnej postavy, z ktorej možno odvodit’ dalšie sekundárne konflikty na osi „bytie - nebytie, vedomie - podvedomie, racionalita - iracionalita“ 28 . Kedže objektívna realita svojou uspôsobenost'ou nedokáže naplnit' nároky subjektu postavy, postava v závere tohto konfliktu rezignuje, v dôsledku čoho býva ladenie Andrejevovej tvorby zákonite pesimistické. Rezignácia zároveň ešte väčšmi umocňuje dojem odcudzenia postavy, ktorý spisovatel' na ploche deja účelovo vytvára. Výsledkom takéhoto postupu je „тотальное очуждение окружающего мира“淀: „И все было чужое. Дерево было чужое, и закат чужой, и вода чужая..." ${ }^{30}$.

Ďalšou charakteristickou črtou Andrejevovej poetiky (a poetiky literárneho expresionizmu vo všeobecnosti) je intenzifikácia daného subjektívno-epického konfliktu sugestívnou implikáciou vlastného pohladu na svet s cielom „максимальной субъективности повествования “"31. V tomto smere možno hovorit’ o identite autora a literárnej postavy/rozprávača, ktorá sa realizuje tak, že „autor ,zverí vyprávanie postave“32 alebo sa „nepriamo stotožní s rozpoložením postavy a ,prepožičia 'autorskú reč na vyjadrenie jej subjektívneho aspektu“"33. Autor a jeho hrdina sú preto „настолько взаимозаменяемы, что читателю приходится верить обоим.“34. Tento autorský zámer sa prejavuje častou frekvenciou zámen, predovšetkým zámena „ja“ („, mym впервые я почувствовал это. Я ясно увидел, что эти люди, молчаливо шагающие

28 DÚBRAVSKÁ, N.: Literárne dielo Leonida Andrejeva v kontexte nemeckej voluntaristickej filozofie. Motus in verbo, 2019, roč. 8 , č. 1, s. 54 .

29 TERECHINA, V. N.: Èkspressionizm v russkoj literature pervoj treti XX veka. Genezis. Istoriko-kul'turnyj kontekst. Poètika: dizertačná práca. Moskva: Rossijskaja akademija nauk, 2006, s. 61.

30 ANDREJEV, L.: Sobranije sočinenij v šesti tomach: Tom 2. Rasskazy. P’jesy 1904-1907. Moskva: Chudožestvennaja literatura, 1990, s. 30.

31 BONDAREVA, N. A.: Tvorčestvo Leonida Andrejeva i nemeckij èkspressionizm: dizertačná práca. Oriol: Orlovskij gosudarstvennyj universitet, 2005, s. 109.

32 MIKO, F.: Estetika výrazu: teória výrazu a štýl. Bratislava: Slovenské pedagogické nakladatel’stvo: Pedagogická fakulta v Nitre, Kabinet literárnej komunikácie, 1969. s. 111.

33 Tamže.

34 BONDAREVA, N. A.: Tvorčestvo Leonida Andrejeva i nemeckij èkspressionizm: dizertačná práca. Oriol: Orlovskij gosudarstvennyj universitet, 2005, s. 113. 
в солнечном блеске $[. . .]^{(35}$ ), ale aj v žánrovej rovine v podobe diel koncipovaných vo forme denníkových zápiskov (napríklad v novelách Красный смех а Мысль).

Optika a svetonázor autora sa na ploche textov stávajú imperatívom, ktorému sa podriadujú všetky komponenty diela - od reči postáv, scenérie, toku deja, až po uplatňované lexikálno-syntaktické prostriedky. Primát Andrejevovej subjektivity neguje objektívnu skutočnost' - tá je v diele prezentovaná tak, ako keby bola prítomná „в субъективной интерпретации автора“"36. Objektívny fakt preto $\mathrm{v}$ autorovej expresionisticky koncipovanej tvorbe de facto neexistuje. Subjektivizácia v Andrejevovej próze a dráme zároveň pôsobí proti individualizmu. Literárne postavy majú v optike spisovatela predovšetkým funkciu prostriedku alebo matérie - plátna, na ktorom môže čitatelovi predostriet’ vlastné citové rozpoloženie. Postava ako indivíduum je podla neho nepodstatná - jej prednost' spočíva v amorfnosti a masovosti, vd’aka ktorej môže vyjadrit vlastný autorský zámer. Autor v dôsledku toho v niektorých prípadoch zachádza až tak daleko, že postavy „превращает [...] в абстракиию" “37.

Na jazykovej úrovni sa expresívnost' manifestuje juxtapozíciou antagonických výrazov, ktoré kontrastujú svojím kladným a záporným zážitkovým vyznením. Táto tendencia sa premietla do frekventovaného používania antonymických dvojíc v podobe podstatných mien: „ожидали короля, а явился шут “38, prídavných mien: „молодые лица, но старые, глубокие морщины““39 с̌і slovies: „родить детей, чтобы убивать " 40 s disonantným vyznievaním.

Ďalším frekventovaným nástrojom sprostredkovania expresívnej disonancie v Andrejevovej tvorbe sú štylistické trópy. Jeho próza a dráma je popretkávaná bohatou spletou metonymií: „рука лежала поверх белого летнего одеяла и почти не отделялась от него - такая она была белая, прозрачная и холодная." 41 , personifikácií „И сдавленная землей и небом задыхалась черная ночь, и глухо и тяжко стонала, и с каждым вздохом выплевывала из недр своих острый

35 ANDREJEV, L.: Sobranije sočinenij v šesti tomach: Tom 2. Rasskazy. P’jesy 1904-1907. Moskva: Chudožestvennaja literatura, 1990, s. 23.

36 BONDAREVA, N. A.: Tvorčestvo Leonida Andrejeva i nemeckij èkspressionizm: dizertačná práca. Oriol: Orlovskij gosudarstvennyj universitet, 2005, s. 110.

37 Tamže, s. 108.

38 ANDREJEV, L.: Sobranije sočinenij v šesti tomach: Tom 2. Rasskazy. P’jesy 1904-1907. Moskva: Chudožestvennaja literatura, 1990, s. 167.

39 Tamže, s. 166.

40 ANDREJEV, L.: Pассказыı. Paríž: Bookking International, 1995. s. 41.

41 ANDREJEV, L.: Sobranije sočinenij v šesti tomach: Tom 1. Rasskazy 1898-1903. Moskva: Chudožestvennaja literatura, 1990, s. 196. 
и жгучий песок, от которого мучительно горели наши язвы“"42, prirovnaní: „[...] они стали распадаться, беззвучно, незаметно, таинственно - как в теле, из которого ушла жизнь и над которым начали свою работу новые, где-то таившиеся силь"“43 a metafor: „тайно от всех целовал гнусные ноги стены“"44. Trópy predstavujú v tvorbe spisovatela „особую форму антропоморфизма, когда явление или понятие олицетворяется, начинает жить собственной независимой жизнью “45. Antropomorfizáciou neživých predmetov (najmä anorganickej prírody) autor vnáša „do zmyslového obrazu prírody ludský, teda kontrastujúci prvok"46. Andrejev tak zmazáva hranicu medzi živým a neživým - neživý objekt nadobúda ludské kvality a začína $\mathrm{v}$ diele plnit’ funkciu takmer plnohodnotnej postavy. Trópy sú už samy o sebe expresívne, pretože v nich „obraz zápasí s primárnym významom “47. Amplifikáciou antropomorfných trópov preto autor vnáša do textu ešte väčšiu mieru expresívnosti. Expresívna kvalita sa na ploche spisovatelovej tvorby dostáva do popredia aj prostredníctvom účelového kumulovania výrazov (predovšetkým substantív, adjektív a slovies). Toto kumulovanie sleduje autorský zámer, ktorým je sugestívna hyperbolizácia prvkov, ktoré sú z pohladu spisovatela sémanticky nosné, ako jeden z dalších prejavov subjektivizácie jeho prózy a drámy. Opakovanie pôsobí proti dynamike deja a čitatelovi prakticky znemožňuje sledovanie sujetovej schémy diela. Dej ako taký sa v dôsledku toho v Andrejevovom diele stáva druhoradým ustupuje do úzadia. Na jeho úkor sa do popredia dostáva účelová deformácia autorského naratívu, ktorá má v diele svoje významové opodstatnenie. Opakovanie má v spisovatelovej tvorbe zvyčajne podobu anafory, epanastrofy alebo pleonazmov.

\section{Záver}

Expresívnost' poetiky ruského prozaika a dramatika Leonida Andrejeva možno interpretovat' ako reakciu na ideologickú schizmu na prelome 19. a 20. storočia, ktorá sa na poli literatúry prejavovala najmä v podobe tenzie medzi dominantným formalistickým a funkcionalistickým prístupom k povahe literárneho diela. Gro

42 Tamže, s. 322-323.

43 ANDREJEV, L.: Sobranije sočinenij v šesti tomach: Tom 2. Rasskazy. P’jesy 1904-1907. Moskva: Chudožestvennaja literatura, 1990, s. 154.

44 ANDREJEV, L.: Sobranije sočinenij v šesti tomach: Tom 1. Rasskazy 1898-1903. Moskva: Chudožestvennaja literatura, 1990, s. 325 .

45 BONDAREVA, N. A.: Tvorčestvo Leonida Andrejeva i nemeckij èkspressionizm: dizertačná práca. Oriol: Orlovskij gosudarstvennyj universitet, 2005, s. 102.

46 MIKO, F.: Estetika výrazu: teória výrazu a štýl. Bratislava: Slovenské pedagogické nakladatel’stvo: Pedagogická fakulta v Nitre, Kabinet literárnej komunikácie, 1969. s. 114.

47 Tamže, s. 119. 
tohto konfliktu tkvelo $\mathrm{v}$ tom, že formalizmus $\mathrm{v}$ literárnom texte zdôrazňoval primát estetického tvaru na úkor epickej zážitkovosti, čím v diele oslaboval pozíciu autora. Vzájomný antagonizmus daných orientácií sa na ploche Andrejevovej tvorby premietol do základného konfliktu na osi subjekt - objekt, príznačného pre literárny expresionizmus, a z neho odvodeného prvku disonancie, ktorý úmerne preniká tematickou i jazykovou rovinou autorových diel. Predložená štúdia tento disonantný prvok interpretovala cez prizmu sústavy výrazových kategórií slovenského jazykovedca Františka Mika, ktorý disonanciu v expresionisticky ladenej literatúre definuje ako sémantickú disproporciu medzi objektívnou a subjektívnou zložkoudiela.

\section{Literatúra:}

ANDREJEV, L.: Sobranije sočinenij v šesti tomach: Tom 1. Rasskazy 1898-1903. Moskva: Chudožestvennaja literatura, 1990, 638 s. ISBN 5-280-00977-6.

ANDREJEV, L.: Sobranije sočinenij v šesti tomach: Tom 2. Rasskazy. P’jesy 1904-1907. Moskva: Chudožestvennaja literatura, 1990, 558 s. ISBN 5-280-00979-2.

ANDREJEV, L.: 1995. Rasskazy. Paríž: Bookking International, 1995. 509 s. ISBN 287714-276-0.

BONDAREVA, N. A.: Tvorčestvo Leonida Andrejeva i nemeckij èkspressionizm: dizertačná práca. Oriol: Orlovskij gosudarstvennyj universitet, 2005, $205 \mathrm{~s}$.

DÚBRAVSKÁ, N.: Literárne dielo Leonida Andrejeva v kontexte nemeckej voluntaristickej filozofie. Motus in verbo, 2019, roč. 8, č. 1, s. 52-63. ISSN 1339-0392.

DÚBRAVSKÁ, N.: Sémantická disproporcia a jej výrazové implikácie na ploche prekladov vybraných prozaických diel Leonida Andrejeva. Nová filologická revue, 2019, roč. 11, č. 1, jún 2019, s. 102-113. ISSN 1338-0583.

HABERMAS, J.: Teória jazyka a východiská sociálnych vied: (úvodné štúdie a dodatky $k$ teórii komunikatívneho konania). Bratislava: Kalligram, 2011. 669 s. ISBN 978-80-8101-403-1.

MIKO, F.: Estetika výrazu: teória výrazu a štýl. Bratislava: Slovenské pedagogické nakladatel’stvo: Pedagogická fakulta v Nitre, Kabinet literárnej komunikácie, 1969. $292 \mathrm{~s}$.

MURPHY, R.: Teoretizace avantgardy: modernismus, expresionismus a problém postmoderny. Brno: Host, 2010, 294 s. ISBN 978-80-7294-269-5.

NIETZSCHE, F.: Tak vravel Zarathustra. Kniha pre všetkých a pre nikoho. Bratislava: Iris, 2002. 236 s. ISBN 8o-89018-28-9. 
TERECHINA, V. N.: Èkspressionizm v russkoj literature pervoj treti XX veka. Genezis. Istoriko-kul'turnyj kontekst. Poètika: dizertačná práca. Moskva: Rossijskaja akademija nauk, 2006, $398 \mathrm{~s}$.

\section{About the author}

\section{Natália Dúbravská}

Matej Bel University, Faculty of Arts, Department of Slavic Languages, Banská Bystrica, Slovakia

natalia.dubravska@student.umb.sk 